\title{
Pembersihan Isi Sel Akar dan Jenis Warna Tinta untuk Deteksi Cendawan Mikoriza Arbuskula
}

\section{Clearing of Root Cell Content and Types of Ink Stain for Arbuscular Mycorrhizal Fungal Detection}

\author{
SITI SULFIAH, NAMPIAH SUKARNO*, AGUSTIN WYDIA GUNAWAN \\ Departemen Biologi, Fakultas Matemetika dan Ilmu Pengetahuan Alam, IPB University, Bogor 16680, Indonesia
}

Diterima 2 Mei 2021/Disetujui 22 Juli 2020

\begin{abstract}
Arbuscular mycorrhizal (AM) fungi form mutualistic symbiosis with root of host plant. Staining technique to detect AM fungi usually used hazardous chemical. The ink stain and vinegar were used as an alternative technique to replace trypan blue and lactic acid in root staining method. This study aimed to determine time for clearing root cell contents and ink stain type to visualize the best $\mathrm{AM}$ fungal structures within the root observed under light microscope. Pueraria phaseoloides var. javanica roots colonized by AM fungi were cut into $1 \mathrm{~cm}$ long, cleared in KOH solution and stained. In this study four clearing time were done vis $5,10,15$, and 20 minutes, and four stains were used namely Shaeffer black ink, Parker Quink blue ink, blue stamp ink, and trypan blue. Twenty stained roots were taken randomly from each tratment, and observed. Root clearing process for 20 minutes showed the best result. Only Shaeffer black ink and trypan blue produced clear structure of external hyphae, internal hyphae, vesicles and arbuscules. Arbuscular structure stained only by Shaeffer black ink and trypan blue. This indicated that Shaeffer black ink could be used as an alternative stain to detect $A M$ fungi within the root of host plant.
\end{abstract}

Key words: arbuscular mycorrhizal fungi, ink stain, trypan blue, vinegar

\section{PENDAHULUAN}

Mikoriza arbuskula (MA) ialah salah satu bentuk asosiasi simbiosis mutualisme antara cendawan dan organ tumbuhan yang berada dalam medium tumbuh. Struktur asosiasi ini tidak dapat dilihat dengan mata telanjang dan untuk mendeteksinya digunakan pewarnaan akar. Pada awalnya para peneliti menggunakan zat warna biru tripan (Phillips dan Hayman 1970; Liesche et al. 2015), asam fuksin (Kormanik et al. 1980), Chlorazol black E dan biru anilin (Brundrett et al. 1984). Akan tetapi, zat warna tersebut berbahaya bagi kesehatan karena dapat menyebabkan kanker dan tidak ramah lingkungan (Hulse 2018).

Sebuah terobosan besar dilakukan oleh Vierheilig et al. (1998) untuk menjawab permasalahan penggunaan zat warna yang berbahaya bagi kesehatan dan lingkungan. Mereka menggunakan tinta tulis dan cuka untuk mewarnai cendawan MA yang mengkolonisasi akar tumbuhan inang, namun teknik yang ramah lingkungan dan aman ini tidak banyak digunakan sampai sekarang. Hal ini karena tidak semua tinta tulis dapat mewarnai akar.

*Penulis korespondensi: +62-251-8622833

E-mail: nampiah@apps.ipb.ac.id
Keberhasilan pewarnaan cendawan MA dipengaruhi oleh beberapa faktor, salah satunya ialah proses pembersihan isi sel akar menggunakan larutan $\mathrm{KOH} 10 \%$. Proses pembersihan isi sel akar dipengaruhi di antaranya oleh suhu, waktu, jenis dan umur tanaman, dan pigmen akar (Koske dan Gemma 1989). Penelitian ini bertujuan menentukan waktu pembersihan isi sel akar dan jenis zat warna tinta sehingga hasil pewarnaan cendawan MA dapat diamati dengan jelas.

\section{BAHAN DAN METODE}

Akar yang bersimbiosis membentuk MA yang digunakan berasal dari biakan pot menggunakan inang Pueraria phaseoloides var. javanica yang diinokulasi dengan inokulum cendawan MA Acaulospora tuberculata, Glomus manihotis, dan Glomus etunicatum. Penelitian ini dirancang secara faktorial menggunakan akar terkolonisasi dengan cendawan MA dari biakan pot berumur 16 minggu.

Penelitian ini disusun dengan perlakuan pembersihan isi sel akar dengan empat faktor waktu pembersihan menggunakan $\mathrm{KOH} 10 \%$ selama 5, 10 , 15 , dan 20 menit serta perlakuan zat warna dengan empat faktor, yaitu menggunakan tinta Shaeffer 
hitam, tinta Parker Quink biru, tinta stempel biru, dan biru tripan. Penelitian ini diulang sebanyak 3 kali, masing-masing ulangan menggunakan akar yang dipanen dari 2 biakan pot.

Akar yang bersimbiosis dipanen dari tanaman dengan cara batang tanaman dipangkas dan perakarannya dicuci. Akar muda yang berfungsi dalam penyerapan nutrisi dipotong-potong dengan ukuran $1 \mathrm{~cm}$. Sebanyak total 400 potongan akar yang bersimbiosis diambil secara acak dan dibagi menjadi 4 bagian yang masing-masing bagian dibersihkan isi selnya menggunakan $\mathrm{KOH} 10 \%$ selama 5, 10, 15, dan 20 menit. Akar dari masing-masing perlakuan perendaman dengan $\mathrm{KOH} 10 \%$, selanjutnya diwarnai menggunakan zat warna. Terdapat 4 pewarna yang digunakan yaitu tinta Shaeffer hitam, tinta Parker Quink biru, tinta stempel biru, dan biru tripan. Pewarna biru tripan digunakan sebagai perlakuam kontrol.

Pembersihan akar dalam $\mathrm{KOH} 10 \%$ dilakukan pada suhu $90^{\circ} \mathrm{C}$ dengan waktu perlakuan 5,10 , 15, dan 20 menit, kemudian diwarnai. Pewarnaan akar menggunakan pewarna tinta mengikuti metode Vierheillig et al. (1998). Potongan akar dipanaskan dalam tinta-cuka 5\% dari masing-masing tinta yang digunakan sebagai perlakuan $(1 \mathrm{ml}$ tinta dan $19 \mathrm{ml}$ cuka $5 \%$ ) pada suhu $90^{\circ} \mathrm{C}$ selama 3 menit, kemudian zat warna dibuang dan akar dibilas dengan larutan cuka $2.5 \%$.

Pewarnaan biru tripan yang digunakan sebagai kontrol, setelah pembersihan isi sel, akar diwarnai mengikuti metode Phillips dan Hayman (1970). Akar direndam dalam $\mathrm{HCl}$ 1\% selama 30 menit dan dipanaskan dalam biru tripan selama 3 menit pada suhu $90^{\circ} \mathrm{C}$, lalu direndam dalam gliserol $50 \%$ selama 60 menit.

Sebanyak 20 potong akar dari setiap perlakuan diambil secara acak dari 25 potong akar yang diwarnai untuk diamati kejelasan penampakan struktur candawan MA di dalam akar menggunakan mikroskop majemuk. Struktur cendawan MA yang diamati ialah hifa internal, hifa eksternal, vesikula, dan arbuskula. Struktur cendawan MA yang dihitung ialah struktur yang dapat dilihat walaupun masih tampak terdapat sisa sitoplasma. Selanjutnya struktur cendawan MA yang teramati digunakan untuk menentukan kolonisasi MA pada setiap perlakuan. Kolonisasi MA dihitung berdasarkan pada rumus yang dilaporkan oleh McGonigle et al. (1990).

Total bidang

Kolonisasi mikoriza $=$ pandang ber-MA $\times 100 \%$ arbuskula

Total bidang pandang yang diamati
Data kolonisasi MAdalam akardiolah menggunakan perangkat lunak SAS 9.1.3 yang selanjutnya dianalisis dengan uji Duncan pada taraf 5\%.

\section{HASIL}

Hasil pengamatan mikroskopi akar P. phaseoloides var. javanica yang bersimbiosis pada perlakuan waktu pembersihan isi sel akar tampak berbeda. Proses pembersihan isi sel akar selama 5 menit menampakkan isi sel akar yang belum bersih (Gambar 1a-d). Sisa sitoplasma terlihat keruh dan menghalangi penampakan stuktur cendawan MA saat pengamatan. Waktu pembersihan isi sel akar yang lebih lama berangsur semakin bersih sehingga menambah penampakan struktur CMA di dalam akar (Gambar 1e-k). Waktu pembersihan 20 menit menunjukkan isi sel yang terlihat bersih (Gambar 11-p). Isi sel akar yang bersih menunjukkan kejelasan struktur cendawan MA ketika dilakukan pengamatan.

Cendawan MA yang diwarnai dengan tinta Shaeffer hitam menunjukkan isi sel akar dan struktur MA berwarna cokelat bening hingga cokelat. Struktur hifa internal, hifa eksternal, dan vesikula terlihat cokelat (Gambar 1a, e, i, dan m), sedangkan arbuskula terlihat hitam kebiruan (Gambar 2a, b, dan c). Tinta Parker Quink biru mewarnai isi sel akar maupun struktur cendawan MA menjadi biru muda (Gambar 1b, f, j, dan n). Tinta stempel biru mewarnai isi sel akar maupun cendawan MA menjadi hijau kekuningan (Gambar 1c, g, k, dan o). Pewarnaan struktur cendawan MA dengan tinta stempel biru sulit diamati karena warnanya menyerupai isi sel akar. Isi sel akar dan cendawan MA yang diwarnai tripan biru menjadi berwarna biru tua (Gambar 1d, h, 1, dan p; Gambar 2d, e, dan f).

Hifa eksternal, hifa internal, dan vesikula merupakan bagian dari struktur cendawan MA yang terlihat pada semua perlakuan waktu pembersihan isi sel dan jenis zat warna yang digunakan pada akar P. phaseoloides var. javanica berumur 16 minggu. Arbuskula dapat diamati menggunakan pewarna tinta Shaeffer hitam dan biru tripan pada pembersihan isi sel akar selama 10, 15, dan 20 menit (Gambar 2), sedangkan zat warna lainnya tidak dapat mendeteksi adanya arbuskula.

Interaksi antara waktu pembersihan isi sel akar dan zat warna yang digunakan tidak menunjukkan perbedaan dalam hal kolonisasi cendawan MA, demikian juga waktu pembersihan sel akar $P$. phaseoloides var. javanica. Hanya zat warna yang menunjukkan perbedaan pada kolonisasi cendawan MA (Tabel 1). Zat warna tinta Shaeffer hitam menunjukkan respons yang sama dengan biru tripan, sedangkan keduanya berbeda dengan tinta Parker Quink biru dan tinta stempel biru. 


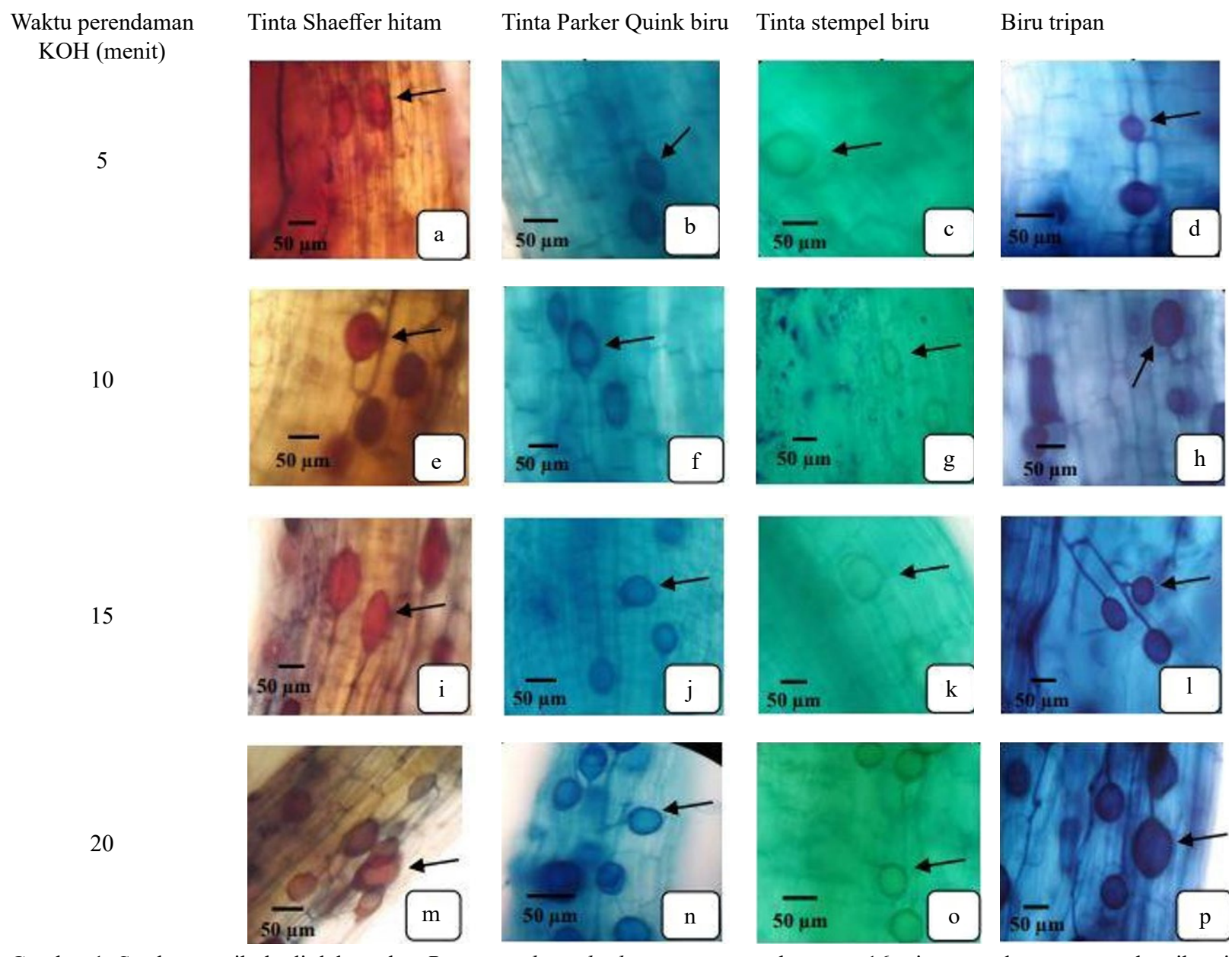

Gambar 1. Struktur vesikula di dalam akar Pueraria phaseoloides var. javanica berumur 16 minggu pada proses pembersihan isi sel selama 5 menit (a-d), 10 menit (e-h), 15 menit (i-l), dan 20 menit (m-p) dan penggunaan zat warna tinta Shaeffer hitam (a, e, i, m), tinta Parker Quink biru (b, f, j, n), tinta stempel biru (c, g, k, o), dan zat warna biru tripan (d, h, 1, p) $(400 \mathrm{x}$, bar $=50 \mu \mathrm{m})$

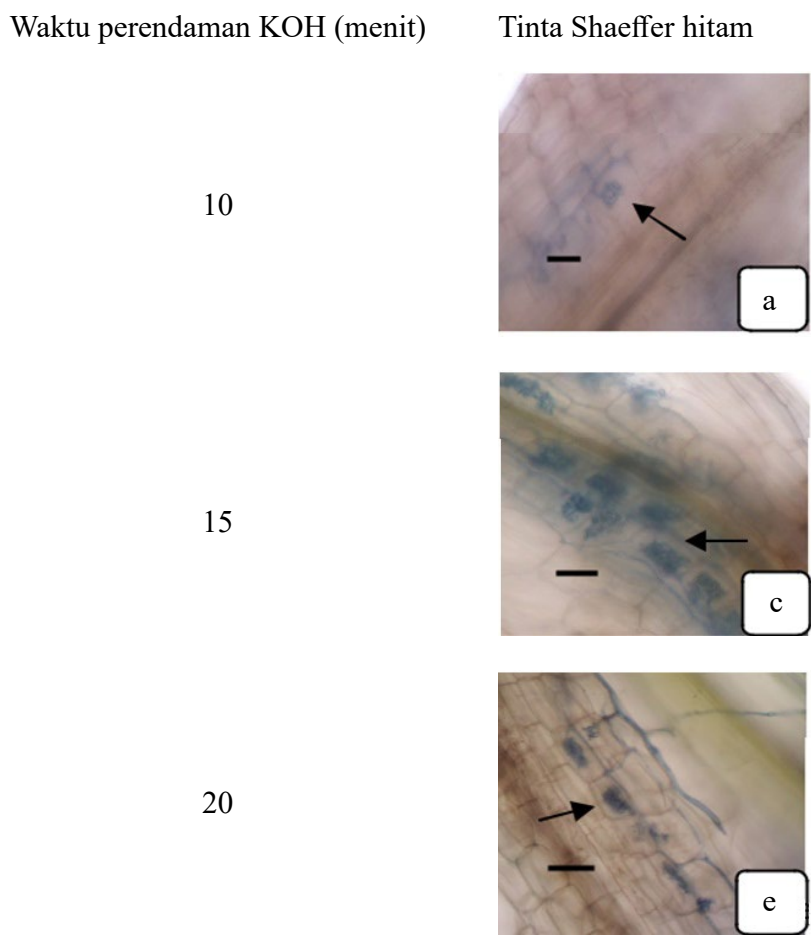

Biru tripan
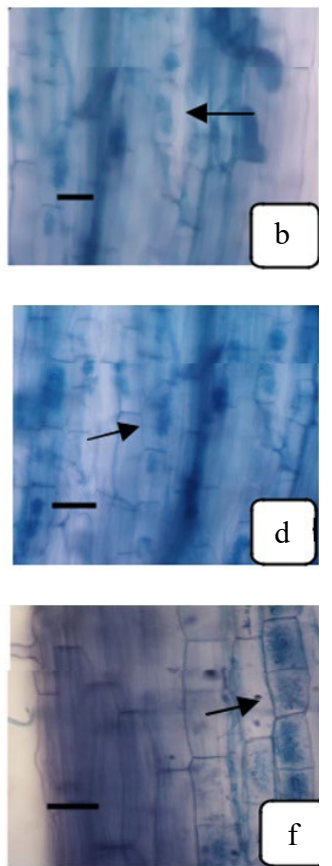

Gambar 2. Struktur arbuskula di dalam akar Pueraria phaseoloides var. javanica pada proses waktu pembersihan isi sel selama 10 menit (a, b), 15 menit (c, d), dan 20 menit (e, f) dan pewarnaan menggunakan tinta Shaeffer hitam (a, c, e) dan zat warna biru tripan $(b, d, f),(400 x, b a r=50 \mu \mathrm{m})$ 
Tabel 1. Kolonisasi cendawan mikoriza arbuskula (CMA) pada akar Pueraria phaseoloides var. javanica dengan empat waktu pembersihan isi sel menggunakan $\mathrm{KOH} 10 \%$ dan empat zat warna

\begin{tabular}{ccccc}
\hline \multirow{2}{*}{ Waktu pembersihan isi sel (menit) } & \multicolumn{4}{c}{ Kolonisasi cendawan MA yang diwarnai dengan } \\
\cline { 2 - 5 } & Sh & PQb & Sb & Bt \\
\hline 5 & $81.33 \mathrm{a}$ & $72.33 \mathrm{~b}$ & $53.67 \mathrm{c}$ & $73.67 \mathrm{~b}$ \\
10 & $88.33 \mathrm{a}$ & $73.67 \mathrm{~b}$ & $59.33 \mathrm{c}$ & $78.00 \mathrm{~b}$ \\
15 & $92.00 \mathrm{a}$ & $78.33 \mathrm{c}$ & $62.00 \mathrm{~d}$ & $86.00 \mathrm{~b}$ \\
20 & $98.33 \mathrm{a}$ & $83.33 \mathrm{~b}$ & $67.33 \mathrm{c}$ & $91.33 \mathrm{a}$ \\
\hline
\end{tabular}

Sh, Tinta Shaeffer hitam; PQb, Tinta Parker Quink biru; SB, tinta stempel biru; tb, tripan biru; angka yang diikuti oleh huruf yang sama pada satu baris tidak berbeda nyata pada taraf uji 5\%

\section{PEMBAHASAN}

Keberhasilan pewarnaan bergantung pada proses pembersihan isi sel akar. Pembersihan isi sel akar dengan $\mathrm{KOH} 10 \%$ bertujuan membersihkan sitoplasma (Phillips dan Hayman 1970) dan metabolit sekunder yang terdapat pada dinding sel dan sitoplasma sel akar (Vierheillig et al. 2005; Wilkes et al. 2019). Pada umumnya pewarnaan sel cendawan MA dilakukan dalam kondisi asam karena zat warna akan diikat oleh hifa yang sebagian besar dinding selnya tersusun dari kitin. Pengondisian supaya akar dalam suasana asam setelah proses pembersihan isi sel, umumnya menggunakan $\mathrm{HCl}$ 1\% (Phillips dan Hayman 1970), tetapi Vierheillig et al. (1998) menggunakan larutan cuka 5\% untuk menggantikan $\mathrm{HCl}$ 1\%. Penggunaan cuka lebih aman bagi kesehatan dibandingkan dengan $\mathrm{HCl} 1 \%$, selain itu cuka juga lebih murah dan mudah diperoleh dibandingkan dengan dengan $\mathrm{HCl}$.

Proses pembersihan isi sel akar memerlukan waktu yang berbeda bergantung pada kondisi akar, spesies dan umur tanaman. Pembersihan isi sel untuk akar tidak berpigmen (tomat) memerlukan waktu selama 60 menit dan akar berpigmen (kacang tanah) selama 120 menit pada suhu $90^{\circ} \mathrm{C}$ (Phillips dan Hayman 1970), sedangkan metode Vierheillig et al. (1998) selama 3-15 menit.

Pembersihan isi sel dengan metode Vierheillig et al. (1998) selain bergantung pada kondisi akar, spesies dan umur tanaman, juga bergantung pada jenis tinta. Pembersihan isi sel akar buncis dilakukan dalam $\mathrm{KOH} 10 \%$ selama 5 menit, sedangkan akar ketimun lebih pendek waktunya ialah 3 menit jika menggunakan tinta warna hitam dan biru. Tinta warna merah memerlukan waktu pembersihan isi sel yang lebih lama, akar buncis selama 15 menit dan akar ketimun selama 5 menit. Pada penelitian ini pembersihan isi sel akar $P$. phaseoloides var. javanica yang tidak berpigmen memerlukan waktu selama 20 menit untuk mendapatkan hasil yang optimal.

Hidrogen peroksida digunakan oleh Phillips dan Hayman (1970) untuk menjernihkan akar berpigmen. Pada penelitian ini hidrogen peroksida tidak digunakan karena akar $P$. phaseoloides var. javanica tidak berpigmen.
Biru tripan merupakan zat warna yang paling banyak digunakan untuk mendeteksi kolonisasi cendawan MA oleh para peneliti. Kombinasi tinta-cuka diusulkan oleh Vierheillig et al. (1998) sebagai alternatif pengganti biru tripan. Teknik ini selain membutuhkan biaya yang lebih murah juga dapat digunakan untuk jumlah sampel yang besar (Vierheillig et al. 2005; Hallasgo et al. 2020). Penampakan struktur cendawan MA di dalam akar juga sangat jelas (Wilkes et al. 2019; Hallasgo et al. 2020; Kowal et al. 2020). Sayangnya sampai saat ini para peneliti lebih suka menggunakan biru tripan dibandingkan dengan dengan tinta-cuka. Pewarnaan cendawan MA menggunakan tinta-cuka belum mendapat perhatian. Salah satu alasannya ialah tidak semua tinta dapat digunakan untuk mewarnai cendawan MA.

Kualitas pewarnaan menggunakan tinta-cuka bergantung pada warna dan merek tinta. Vierheillig et al. (1998) melaporkan berbagai warna tinta dari beberapa merek. Warna tinta ungu dan hijau secara umum tidak cocok untuk mewarnai cendawan MA. Tinta hitam untuk semua merek (Carrefour, Pelikan, Shaeffer, dan Cross) dan beberapa tinta biru (Pelikan) serta merah (Parker) dapat mewarnai cendawan MA. Tinta Shaeffer hitam memiliki kontras yang sangat baik. Nusantara (2011) menggunakan tinta Quink biru untuk mewarnai cendawan MA pada akar jati (Tectona grandis). Dalam penelitian ini tinta Shaeffer hitam dan Parker Quink biru lebih baik untuk mewarnai cendawan MA pada $P$. phaseoloides var. javanica dibandingkan dengan dengan tinta stempel biru. Tinta Shaeffer hitam memberikan hasil lebih baik dari tinta Parker Quink biru dan biru tripan sebagai pewarna yang umum digunakan.

Arbuskula merupakan struktur penting cendawan MA yang berkembang pada akar muda yang berfungsi sebagai penyerap nutrisi, dan luruh seiring bertambahnya umur akar. Struktur arbuskula dibentuk oleh semua cendawan MA, sedangkan struktur vesikula tidak dibentuk oleh semua cendawan MA. Cendawan MA Gigaspora dan Scutellospora, hanya memiliki struktur arbuskula dalam asosiasinya dengan akar tumbuhan. Arbuskula merupakan struktur yang sangat penting dalam pengamatan kolonisasi. Oleh 
karena itu, kualitas pewarnaan yang baik ialah ketika arbuskula dapat diwarnai. Tinta Shaeffer hitam dan biru tripan dapat mewarnai arbuskula, tetapi jumlah yang dapat diamati tidak banyak. Meskipun akar yang digunakan dalam penelitian ini merupakan akar yang masih muda, tetapi tanaman telah berumur 16 minggu dan ruang tumbuh perakaran di dalam biakan pot terbatas. Tinta Shaeffer hitam dapat dicoba untuk mewarnai akar yang bersimbiosis MA dengan umur tanaman yang lebih muda dari 16 minggu sehingga kuantitas arbuskula yang dapat dideteksi lebih banyak.

Pewarnaan dengan tinta Shaeffer hitam memperlihatkan kolonisasi cendawan MA lebih baik dari pewarnaan dengan biru tripan (Tabel 1). Oleh sebab itu, tinta Shaeffer hitam dapat dijadikan sebagai alternatif zat warna pengganti untuk biru tripan dalam pewarnaan kolonisasi cendawan MA. Selain itu, pewarnaan dengan tinta Shaeffer hitam relatif murah dan lebih aman bagi kesehatan dan lingkungan.

\section{DAFTAR PUSTAKA}

Brundrett MC, Piche Y, Peterson RL. 1984. A new method for observing the morphology of vesicular arbuscular mycorrhizae. Canadian Journal of Botany 62:2128-2134.

Hallasgo AM, Spangl B, Steinkellner S, Hage-Ahmed. 2020. The fungal endophyte Serendipita williamsii does not affect phosphorus status but carbon and nitrogen dynamics in asbuscular mycorrhizal tomato plants. Journal of Fungi 6:1-16.

Hulse DJ. 2018. Review of comprehensive staining technique used to differentiate arbuscular mycorrhizal fungi from plant root tissues. Acta Scientific Agriculture 2:39-44.
Kormanik PP, Bryan WC, Schultz RC. 1980. Quantification of vesicular arbuscular mycorrhizae in plant roots. Canadian Journal of Microbiology 26:536-538.

Koske RE, Gemma JN. 1989. A modified procedure for staining roots to detect VA mycorrhizas. Mycological Research 92:486-488.

Kowal J, Arrigoni E, Lane S. 2020. Acidified blue ink-staining procedure for the observation of fungal structure inside roots of two disparate plant lineages. Bio-protocal 10:e3786. DOI: $10.21769 /$ BioProtoc3786

Liesche J, Marek M, Gunther-Pomorski T. 2015. Cell wall staining with trypan blue enables quantitative analysis of morphological changes in yeast cells. Frontiers in Microbiology 6:1-4.

McGonigle TP, Miller MH, Evans DG, Fairchild GL, Swan JA. 1990. A new method which gives an objective measure of colonization of root by vesicular arbuscular mycorrhizal fungi. New Phytologist 115:495-501.

Nusantara AD. 2011. Pengembangan produksi inokulan fungi MA berbasis bahan alami dan pemanfaatannya untuk produksi bibit jati (Tectona grandis 1.f) [Disertasi]. Bogor, Indonesia: Institut Pertanian Bogor.

Phillips JM, Hayman DS. 1970. Improved procedures for clearing roots and staining parasitic and vesicular arbuscular mycorrhizal fungi for rapid assessment of infection. Transmission of British Mycological Society 55:58-161.

Vierheilig H, Coughlan AP, Wyss U, Piche Y. 1998. Ink and Vinegar, a simple staining technique for arbuscularmycorrhizal fungi. Applied and Environmental Microbiology 64:5004-5007.

Vierheilig H, Schweiger P, Brundrett M. 2005. An overview of methods for the detection and observation of arbuscular mycorrhizal fungi in roots. Physiologia Plantarum 125: 393-404.

Wilkes TI, Warner DJ, Edmonds-Brown V, Davies KG, Denholm I. 2019. A comparison of methodologies for the staining and quantification of intracellular components of arbuscular mycorrhizal fungi in the root cortex of two varietas of winter wheat. Access Microbiology 2019:2. DOI:10.1099/ acmi.0.000083 